\title{
Evaluation of Listening Skill of ELT Textbook at Secondary School Level
}

\author{
Mumtaz Ahmed (Corresponding author) \\ Govt. Postgraduate College of Science Faisalabad Pakistan \\ E-mail: webmumtaz@gmail.com \\ Humaira Yaqoob \\ University of Sargodha Women Campus Faisalabad Pakistan \\ E-mail: humaira.yaqoob4@gmail.com \\ Maimoona Yaqoob \\ University of Sargodha Women Campus Faisalabad Pakistan \\ E-mail: monafasal@gmail.com
}

Doi:10.7575/aiac.alls.v.6n.3p.225

Received: 21/02/2014

URL: http://dx.doi.org/10.7575/aiac.alls.v.6n.3p.225

Accepted: 29/04/2015

\begin{abstract}
Textbook evaluation means development of textbook that is based on rigorous research. In Pakistan text books are designed on communicative language teaching which focuses on communication. Morley (1991) has asserted that listening has a critical role in communication and in language acquisition because the better the students understand, the better they will be able to speak. In our text books, listening practices (text and activities) are missing, and listening plays a secondary role as compared to speaking, as it is part of oral work that are dialogues and role play, neglecting that during conversation in English our students face hurdles in quick thinking and accurate predicting because of ignoring listening skill which help in learning sound, rhythm, intonation, pronunciation, vocabulary and grammatical details. The researchers' intention here is to put different views on importance of listening skill and to evaluate English Text Books prescribed in Punjab government school whether they contain listening material, corresponding activities and related audio video material in text books.
\end{abstract}

Keywords: Evaluation, listening skill, ELT, textbook, Punjab Textbook Board (PTB)

\section{Introduction}

\subsection{Significance of text book}

Text Book is the most important teaching tool that is used formally and informally situation of instruction and also effective in self study by learners. Marsh (1992) has said that it is important tool that is used by teacher to motivate learner to give them maximum understanding about topic and problem. Text Book plays an essential role in teaching and learning English as Hutchinson and Torres (1994) consider it necessary input into classroom in shape of text material, activities and explanation.

\subsection{Importance of textbook evaluation}

Rea-Dickins and Germaine (1994, p.4) has asserted that "Evaluation is an intrinsic part of teaching and learning". Ellis (1997) asserts that text book evaluation helps teacher to make appropriate judgment and effectiveness of material which they to use in class. Sheldon (1988) also added that evaluation of text book is useful for teacher to have knowledge about material and its merits and demerits. According to Nunan (1992) evaluation is not only assembling the information but also interpreting the information to make valuable judgment.

\subsection{Purpose of textbook evaluation}

The purpose of material evaluation may be (a) selecting a suitable text book that matches the context in which it is going to be used as Grant (19987) has said 'Perfect book does not exist' (b) to identify particular strength and weakness in a text book already exist (Cunningsworth, 1995) (c) Hutchinson views that it aims to develop teacher's awareness to analyze their own presupposition about the nature of language and learning also focus to set their prerequisite and judging importance of material in teaching learning program.

\subsection{Types of Evaluation}

McGrath (2002) \& Tomlinson (2003) have classified three types of evaluation (a) pre use evaluation, before the particular text has been used in classrooms (b) In/while use evaluation, while it is being used (c) Post use evaluation, after it has been used. Here pre use evaluation is used because as it focus on gaining success in ESL class rooms, is considered more valuable than post use evaluation. Pre use evaluation is more admirable because it help to ensure that 
(a) teaching materials are according to learner's need (b)have adequate relevance to socio cultural atmosphere to target learner (c)finding out the differences among teachers to collaborate the procedure of instruction (d) to examine future and potential performance of course book.

\subsection{Methods of evaluation}

McGrath has proposed different methods of evaluation as (a) The Impressionistic Method, evaluation to asses and determine the practically, objectives and syllabus types of textbook (b) The In depth method, this technique method involves examining the text book thoroughly (c) The Checklist method, using a prepared checklist of criteria against which the text book is assessed.

Here in this book evaluation the check list method is used because of many advantages as (a) it consider all essential elements (b) evaluation is assed in comparatively short duration (c) for comparing more than two books makes its layout practical (d) and having no ambiguity, it is clear for decision making.

\subsection{Checklist for listening skill by Alan Cunningsworth}

1: What kind of listening material is contained in the course?

(a) Does listening form part of dialogue/conversation work?

(b) Are there specific listening passage?

2: If there are specific listening passages, what kinds of activities are based on them-comprehension questions, extracting specific information, etc?

3: If listening material set in a meaningful context?

4: Are there pre-listening tasks, questions etc?

5: What is the recorded material on audio-cassettes like in term of:
(a) Sound quality
(b) Speed of delivery
(c) Accent
(d) Authenticity?

6: Is there any video material for listening?

7: If so, is good use made of the visual medium to provide a meaningful context and how facial expression, gesture, etc?

\section{Listening Skill}

\subsection{Difference between listening and hearing}

Hearing is passive and listening is active in the sense that hearing only knows someone is speaking but listening is intentionally hearing, interpreting, remembering and identifying feelings associated with words. Widdowson (1978) has asserted that hearing is ability to recognize language elements in stream of sound and using phonological and grammatical language system to relate elements each other in clause to conceive the meaning, whereas listening refers receiver's intentionally ability to know what has been said and its functions in the communications.

\subsection{Active listening skill}

Active listening skill is one of the communicative skills which involve intentionally listening, responding, and remembering what speaker means, and it encompasses three major important points.

Purpose: listener suspends one's own frame of reference and judgment.

Tactics: In emotionally charged communication, the listener may listen for feeling, having the ability to interpret a person's body language to develop a more accurate understanding of the speaker's word.

Use: It is used in tutoring, counseling and setting for getting people to open up, avoiding misunderstanding, resolving conflicts and building truth.

\subsection{Types of Listening}

Two types of listening skills are:

Informational Listening: The purpose of informational listening focuses on the listener's ability to understand a speaker's message. In schools and college's students listens the teachers for getting information helpful for quizzers and tests.

Reflective Listening: This as being communicative strategy consists two key steps; seeking to understand a speaker's idea, than offering the idea back to speaker to confirm the idea has been understood correctly.

Active Listening skill one of the interpersonal skills includes;

Note-taking: a crucial skill to encourage and to develop the learners studies by making sense of what they are listening to at that particular point of time an keeping a record for reviving examination and making links with other parts.

Effective questioning:Further skill is effective questioning which learner need to understand his leture's explanation thoroughly. 
Non verbal communication: It is comprised of various elements as Good Posture (concentrates on speaker and avoid of dozing, a talkative neighbor etc), Gesture (non vocal bodily movement as nodding of head), Eye contact between speaker and listener has positive impact on the retention and recall of information, Semantic markers (usually phrases that cue speaker's gestures)

\subsection{The need for better Listening}

In our education we are instructed in better in reading, writing and speaking but listening is neglected skill in communication. Rivers and Moody (1984) has presented a research that an adult spends $40-50 \%$ of communication in listening, $25-30 \%$ in speaking, $11-16 \%$ in reading and $9 \%$ in writing.

Students going abroad for higher studies, or traveler or tourist find it difficult to understand native accent, and participating in seminars, conversation and debates because they found difficulty in effective listening though they speak reasonably.

The listening skill is effective for increased safety, higher productivity, faster learning and better relationship.

\subsection{Listening skill is essential to effective learning}

In the process of learning as listening is a fundamental skill ( Burkill et al, 2000) higher education students rely on this skill because in our learning experiences the formal lectures remain the most common method (Brown and Monogue, 2001). The learning situation that involves discussion and group work can be successfully achieved by focusing on efficiency of listening skill especially of interpersonal skills (De La Harpe, Radloff and Wyber, 2000).

Listening comprehension in language learning can be achieved by interaction of Bottom up and Bottom down listening skills:

Bottom up Skills: involves "decoding" it means to construct a message from sounds, words and phrases.

Bottom down Skills: involves using background knowledge to make inferences about what the speaker intent.

Good L1 listeners have fast automatic bottom up skills and L2 listener rely on Bottom down skills. Rost (2002) has asserted that in our classrooms we focus on to provide pre, during and post listening activities to allow listener to use Bottom down skills to develop Bottom up skills.

\section{Research Methodology}

Our syllabus in Pakistan is usually designed on communicative approach and text book aims to promote communication but our Punjab Textbook Board (PTB) English Language Teaching (ELT) text books are missing focus on listening skill that is the active input for speaking. Through a quick overview of our ELT text books by PTB, it is observed that our text books (a) lacks to provide listening passage or text (b) no related activities are given (c) unavailability of audiolvideo material. And because of these reasons there is (a) no focus on listening practice (b) no specific time is allotted for improvement of listening skills (c) no lesson plan is created and implemented for listening skill.

So, above discussed material motivated me to evaluate ELT Text Book by PTB prescribed in our government schools. To make evaluation successive and effective, a checklist has been selected by Cunningsworth (1995), and a through qualitative method study has been constructed under investigation and research to analyze how much attention has been given on listening skill in our ELT text book and which types of strategies are implemented through our text books. This study would have potential to examine and explore researchers, teachers, curriculum designers, material writers and curriculum development center of the ministry of education.

\section{Analysis}

\subsection{Analysis of ELT grade 9 Punjab Text Book for Listening skill}

Text book grade 9 is selected for analysis of listening skill. Text book stands alone, and doesn't contains students book, teacher book, and audio video material whereas guideline for teacher is provided in the book where required.

In "About the Book" the authors has given salient features about the aims, contents, skills, and activities included in the book. About skills it is proclaimed that "Text based activities will certainly help enhances listening, speaking, reading and writing." In another paragraph it is also mentioned that "Group based activities given at the end of every unit will prepare students for group discussion and presentation. Several open ended questions and activities will encourage critical thinking and higher order learning skills. These activities will help students enhance their listening comprehension skill as well as speaking skill."

\subsection{Listening Material in Text book contains Listening text or is part of dialogue / conversation work:}

According to Cunningsworth (1995) there are two ways to focus on listening skill presenting in text book. One is presented as part of general oral work, dialogue, conversation and role play and in other way listening passage or text is provided.

Through a detailed overview it is observed that our text book has put attention on three skills as reading, writing and speaking but lacks in containing specific strategies for improvement and development of listening skill which is the prominent and naturally input for communication. Teachers speaking to class is only source of listening for learner that is not sufficiently enough for effective listening. In our prescribed text book listening skill is presented and is given importance only in form of dialogue, conversation, or role play and in these activities attention is given to develop speaking skill and effective listening skill is again neglected. 
Table 1. Contents of the Text Book

\begin{tabular}{|c|c|c|c|}
\hline No. & Activities Types & Activity & Guideline For Teacher \\
\hline Unit 1 & Oral Communicative Skills & $\begin{array}{l}\text { Identify and analyze expressions to } \\
\text { agree and disagree politely }\end{array}$ & Help students in discussions \\
\hline Unit 2 & NA & & NA \\
\hline Unit 3 & Oral Communicative Skills & To conduct and give short interview & NA \\
\hline Unit 4 & Oral Communicative Skills & $\begin{array}{l}\text { Offer and respond to greetings and } \\
\text { introductions }\end{array}$ & $\begin{array}{l}\text { Help students use conventions } \\
\text { in different settings for effective } \\
\text { oral communication }\end{array}$ \\
\hline Unit 5 & Oral Communicative Skills & $\begin{array}{l}\text { Express satisfaction and } \\
\text { dissatisfaction politely }\end{array}$ & $\begin{array}{l}\text { Help students use appropriate } \\
\text { expressions }\end{array}$ \\
\hline Unit 6 & Oral Communicative Skills & Asking for directions & $\begin{array}{l}\text { Help students practice the } \\
\text { dialogue with appropriate stress } \\
\text { and intonation }\end{array}$ \\
\hline Unit 7 & Oral Communicative Skills & $\begin{array}{l}\text { Ask and respond to questions of } \\
\text { social nature }\end{array}$ & $\begin{array}{l}\text { Give students good practice in } \\
\text { presenting dialogue with proper } \\
\text { stress and intonation }\end{array}$ \\
\hline Unit 8 & Oral Communicative Skills & $\begin{array}{l}\text { Express, refusal politely, express } \\
\text { hopes and fears, presentation skills }\end{array}$ & $\begin{array}{l}\text { Help students use appropriate } \\
\text { expressions }\end{array}$ \\
\hline Unit 9 & NA & NA & NA \\
\hline Unit 10 & NA & NA & NA \\
\hline Unit 11 & Oral Communicative Skills & Expressions for advice & NA \\
\hline Unit 12 & Oral Communicative Skills & To seek and offer advice & NA \\
\hline
\end{tabular}

The activities given at the end of each unit are of two types. These are "Oral Activity" and "Oral Communication Skill"

1. Oral activities: These focuses on the speaking skill and listening skill is not widely focused.

2. Oral Communication Skill: These activities are planned to improve and develop listening and speaking skill. There are three parts which are important for learners to enhance or develop the following skills.

- Listening: In this way they listen to their teachers and other students allowing student to conceive meanings and interpret contents in speech and conversation.

- Speaking: The students interact with others using appropriate language, clarity, presenting meanings and expressing emotions.

- Reflecting: The students recognize their strength and weaknesses during preparation for and participating in communication activities and getting help to improve it.

These activities given at the end of the each unit are mentioned as "Oral Communicative Skills" In these activities the prominence is also given to speaking skill rather than listening skill and in this case it is as "to put a cart before the horse". In unit 1,for example, Oral communication skill has activity "to identify and analyze expressions to agree and disagree politely" focus on speaking and discussion in class, and also in "help for teacher" teacher are asked to help students in conducting the discussion but no any hint is given about listening skill. And in unit 4 and 5 again teachers are guided to help students on convention for effective oral communication skill and to express satisfaction and dissatisfaction. Further in unit 6 and 7 the intention is to put attention on stress and intonation but in form to conduct the dialogues.

There in our text book for effective listening no text is provided, neither in form of written passage nor in recorded material (Audio \& Video DVDs).

\subsection{Unavailability of activities related to listening skill}

Activities are good tool to make our listening skill effective. Our text book proclaim for having activities to focus on skills but a detail analysis has presented that listening skill related activities are not focused in detail. Three types of activities pre, during and post listening activities are not included in our text book. Pre activities can be used to motivate and to prepare learner for effective listening as picture predicting, thinking answers and creating a scene etc. Pre listening activities are helpful in quick thinking and actual prediction of what to expect. During listening activities are also not available to keep up learner's attention and avoiding becoming passive listener, dozing and neighbor taking. Also post activities are not included to asses and evaluate students understanding. Ignorance of listening skill cut down the importance of listening skill in learner's vision.

\subsection{Unavailability of Audio/Video material}

Nunan (1988) has suggested the teachers to insist the learner to do in class that would be helpful outside the class. In this respect Audio Video materials are considered the superior source that can bring real life in class. Audio Video materials are very effective in learning a foreign language in meaningful and interesting manners. Audio video material 
by practicing eyes and ears can be helpful in providing systematic improvement in language learning. In case of learning foreign language Audio Video material creates a real environment.

In English language acquisition audio material acts as stimulating and facilitating language. For speaking English, learners have to get awareness of its pronunciation, stress, intonation and accent and these can be possible on availability of effective and authentic recording material of related language (elce-Murcia 1996). Along the speech, style, pronunciation and accent can be focused through the standard modal and these can be achieved by authentic listening material that can provide natural input for listener. Same is in the case of video material that is also given importance for providing awareness of facial expressions, gestures and postures.

In our text book audio and video materials are not available and in the process to conduct the activities the primary source of listening is teacher and the other students when they are active in presentation, performing role play activity and conducting dialogue to complete the task of "Oral Communicative skill".

As English is not our native language and our available teachers are not native speakers, we have a great variance in teachers speaking English.

\section{Discussion and Conclusion}

It is generally considered that listening skill is helpful in finding out information about person or event and for our pleasure and interest so, along with it, special attention should be given to make learner effective listener to understand serious lecture, seminars or discussions or important text read aloud. Our Punjab Text Book grade 9 was analyzed and it is evaluated that our book has presented listening skills and activities but these have secondary position as related to speaking skill. Listening material (listening passage \& recorded text) is not available and Audio Video Material and listening related activities are not provided. In our class rooms only source of listening for learner is teacher and other students presenting activities mentioned in "Oral Communicative Skill" and this source is not considered authentic because our available teachers are not English native speakers.

In order to develop our listening skill our Text book should contain:

- Effective and interesting passage should be given in the text book.

- An authentic recorded material should be provided for effective listening to develop pronunciation, stress and intonation, sound quality should be clear for learners to listen effectively, speed of delivery should be appropriate according to learner ability, accent should not too drastically from standard variety the learner are used to from teachers and previous listening, recorded text should be authentic, related to daily life and should give background information and should focus on facial expressions, gesture etc to make listening comprehension effective, authentic and easier.

- In case of activities these should be provided in Text Book in form of pre listening activities to motivate or prepare learner for listening, during listening activities to maintain learner attention and avoiding from becoming passive listener or neighbor talk and dozing etc, and post listening activities for assessing or evaluating learners improvement and success in effective listening. Activities should relate to real and personal life so the learner feels free during listening.

\section{References}

Brown, G. and Manogue, M. (2001). AMEE medical education guide no. 22: Refreshing lecturing: a guide for lecturers. Medical Teacher, 23, 231-244.

Burkill, S. Corey, D. and Healy, M. (2000). Improving students' communication skills. Cheltenham: Geography Discipline Network (GDN).

Cunningsworth, A. (1995). Choosing Your Coursebook. Oxford: Heinemann Publishers Ltd. p.7.

De la Harpe, B., Radloff, A. and Wyber, J. (2000). Quality and generic (professional) skills. Quality in Higher Education, 6, 231-243.

Ellis R (1997). 'The Empirical Evaluation of Language Teaching Materials'. ELT Journal., 51(1): 36-42.

Grant, M. (1987). Making the Most of Your Textbook. London: Longman.

Hutchinson, T. (1987). What is underneath? An interactive view of the material evaluation. In L. E Sheldon (ed.), ELT textbook materials: Problems in evaluation and development, (pp. 37-44), Oxford: Modern English Publications.

Hutchinson T, \& Torres, E. (1994). 'The Textbook as Agent of Change'. ELT Journal, $48: 4$.

McGrath,I. (200). Materials evaluation and design for language teaching. Edinburgh University Press.

Nunan, D. (1999). Second language teaching and learning. Boston: Heinle and Heinle.

Sheldon, L. E. (1988). Evaluating ELT textbooks and materials. ELT Journal, 42, 237-246. http://dx.doi.org/10.1093/elt/42.4.237

Rost, M. (2002). Teaching and researching listening. New York: Pearson.

Widdowson, H. (1978) Teaching Language as Communication. Oxford: OUP. 